\title{
CDX2 expression and perioperative patient serum affects the adhesion properties of cultured colon cancer cells
}

Johanne Davidsen ${ }^{1,2}$, Stine Bull Jessen ${ }^{1,2}$, Sara Kehlet Watt², Sylvester Larsen ${ }^{1,3}$, Katja Dahlgaard ${ }^{1}$, Tove Kirkegaard ${ }^{2}$, Ismail Gögenur ${ }^{2}$ and Jesper T. Troelsen ${ }^{1 *}$ (i)

\begin{abstract}
Background: Colon cancer is one of the most commonly diagnosed types of cancer with surgical resection of the tumor being the primary choice of treatment. However, the surgical stress response induced during treatment may be related to a higher risk of recurrence. The aim of this study was to examine the effect of surgery on adhesion of cultured colon cancer cells with or without expression of the tumour suppressor CDX2.

Method: We enrolled 30 patients undergoing elective, curatively intended laparoscopic surgery for colon cancer in this study. Blood samples were drawn 1 day prior to surgery and $24 \mathrm{~h}$ after surgery. The samples of pre- and postoperative serum was applied to wild type colon cancer LS174T cells and CDX2 inducible LS174T cells and adhesion was measured with Real-Time Cell-Analysis iCELLigence using electrical impedance as a readout to monitor changes in the cellular adhesion.

Results: Adhesion abilities of wild type LS174T cells seeded in postoperative serum was significantly increased compared to cells seeded in preoperative serum. When seeding the CDX2 inducible LS174T cells without CDX2 expression in pre- and postoperative serum, no significant difference in adhesion was found. However, when inducing CDX2 expression in these cells, the adhesion abilities in pre- and postoperative serum resembled those of the LS174T wild type cell line.

Conclusions: We found that the adhesion of colon cancer cells was significantly increased in postoperative versus preoperative serum, and that CDX2 expression affected the adhesive ability of cancer cells. The results of this study may help to elucidate the pro-metastatic mechanisms in the perioperative phase and the role of CDX2 in colon cancer metastasis.
\end{abstract}

Keywords: Colon cancer, CDX2, Tumour suppressor, Surgical stress, Metastasis, Cell adhesion, Perioperative phase

\footnotetext{
* Correspondence: troelsen@ruc.dk

'Department of Science and Environment, Enhanced Perioperative Oncology

(EPeOnc) Consortium, Roskilde University, Universitetsvej 1, 4000 Roskilde,

Denmark

Full list of author information is available at the end of the article
}

(C) The Author(s). 2020 Open Access This article is licensed under a Creative Commons Attribution 4.0 International License, which permits use, sharing, adaptation, distribution and reproduction in any medium or format, as long as you give appropriate credit to the original author(s) and the source, provide a link to the Creative Commons licence, and indicate if changes were made. The images or other third party material in this article are included in the article's Creative Commons licence, unless indicated otherwise in a credit line to the material. If material is not included in the article's Creative Commons licence and your intended use is not permitted by statutory regulation or exceeds the permitted use, you will need to obtain permission directly from the copyright holder. To view a copy of this licence, visit http://creativecommons.org/licenses/by/4.0/ The Creative Commons Public Domain Dedication waiver (http://creativecommons.org/publicdomain/zero/1.0/) applies to the data made available in this article, unless otherwise stated in a credit line to the data. 


\section{Background}

Colon cancer is the third most commonly diagnosed cancer and the second most leading cause of cancerrelated death, accounting for approximately 1 in 10 cancer cases and deaths [1]. Surgical resection of the tumour is the primary choice of treatment but, despite medical and surgical advances, the risk of recurrence in colonic cancer is up to $30 \%$ after curative resection [2]. Manipulation of the tumour during surgery results in an increase in the number of circulating tumour cells [3], and the operation can lead to a surgical stress response (SSR) resulting in reduced anti-tumoral defence [4], as well as an increase in factors favouring an oncogenic environment [5]. Excessive stimulation of cytokine production during the SSR is associated with the risk of postoperative metastasis [6], and pro-inflammatory cytokines, such as IL-1 and TNF- $\alpha$ have been shown to stimulate adhesion in circulating cancer cells [2].

Alternations in cell adhesion is believed to be critical in cancer metastasis [5]. For tumour cells to disengage from the primary tumour, adhesion is downregulated through modification of the cadherin-catenin complex $[7,8]$. Further, the integrity of tight junctions that maintain cell polarity in normal epithelia is diminished by downregulation of claudins [9]. Attachment of metastatic cancer cells to distant tissues is mediated through expression of selectins [10], integrins [11] and members of the immunoglobulin superfamily [12]. Surgical trauma provokes an inflammatory reaction which results in release of cytokines that are shown to increase adhesion of colon carcinoma cells to metastatic sites [13, 14]. This effect of cytokines on the cell adhesion molecules expressed on cancer cells may contribute to the development of metastasis [15].

The transcription factor Caudal type Homeobox 2 (CDX2) is crucial for the homeostasis of the colonic epithelium [16], and has been shown to be at tumour suppressor [17-20]. Lack of CDX2 expression in colon cancer cells is associated with aggressive clinical behaviour and can be used as an adverse prognostic biomarker [21-25]. CDX2 has been reported to be downregulated in colon cancer cells in the invasive front of the tumour $[16,26]$. The downregulation of CDX2, and thereby loss of intestinal identity, has been suggested to be a precursor for metastatic colon cancer to perform epithelial-tomesenchyme transition (EMT) $[16,26,27]$. As the circulating colon cancer cells establish metastasis they undergo mesenchyme-to-epithelia transition (MET) and CDX2 expression is re-established, allowing for it to be used as a marker to determine the primary tumours colonic origin [26]. Overexpression of CDX2 in colon cancer cell lines has shown decreased mobility and dissemination of cancer cells, further implicating fluctuation of CDX2 expression in the metastatic process
[28]. Alterations in CDX2 expression is based on mechanisms such as inflammation and epigenetic regulation, rather than mutations [21, 29].

Through a cell-based assay, measuring cancer cell adhesion in a colon cancer cell culture treated with serum obtained from patients before and after colon cancer surgery, we aimed to examine whether laparoscopic colon cancer surgery affects the adhesion of cancer cells and if CDX2 influences the adhesion abilities of cultured colon cancer cells.

\section{Methods}

\section{Participants}

From January to July 2016, consecutive patients undergoing elective, curatively intended laparoscopic surgery for colon cancer, stage I-III according to Union for International Cancer Control (UICC), at Zealand University Hospital were enrolled in this study. Patients receiving neoadjuvant radio- or chemotherapy, with known immune defects, or previous cancer history, were excluded. All eligible patients received information regarding purpose and methods of the study and were included after giving oral and written consent. The study was conducted in accordance with the Declaration of Helsinki, and the protocol was approved by The Danish National Committee on Health Research Ethics, Region Zealand (file no: 2008-58-0020) and approved by the Danish Data Protection agency (protocol: SJ567).

\section{Setting}

During the perioperative period, patients followed the standard of care for colon cancer in a setting of Enhanced Recovery After Surgery (ERAS), which has been described in detail for the department elsewhere [30]. There were no restrictions on pain management, and all patients were encouraged to take their regular medication after surgery. The choice of anesthetics was determined at a pre-anesthesia interview, and patients received universal anesthesia with either Total Intravenous Anesthesia or volatile inhalational. For induction of anesthesia, propofol $2-3 \mathrm{mg} / \mathrm{kg}$ and remifentanil or sufentanil were administered. Hereafter, all patients received a single intravenous dose of $240 \mathrm{mg}$ gentamycin and $1 \mathrm{~g}$ metronidazole. Patients assigned to Total Intravenous Anesthesia received a continuous infusion of propofol supplemented remifentanil $0.5 \mu \mathrm{g} / \mathrm{kg} / \mathrm{min}$. Patients assigned to volatile inhalation received sevoflurane to a minimum alveolar concentration of $0.7-1.2$ and remifentanil or repeated boli of sufentanil. Prior to extubation, ondansetrone $4 \mathrm{mg}$, sufentanil $0.4-0.6 \mu \mathrm{g} / \mathrm{kg}$, and $1 \mathrm{~g}$ of paracetamol was given. Ropivacaine, $20 \mathrm{~mL}$, was administered locally in the wounds. 


\section{Data collection and processing}

Demographic data was collected through the electronic patient charts including age, gender, smoking status, body mass index (BMI), American Society of Anesthesiologist (ASA) scores, and Charlson Comorbidity Index. The UICC stage was based on pre-operative CT scans and histology results. Blood samples were taken the day prior to surgery, and approximately $24 \mathrm{~h}$ after surgery. Samples were collected in serum separation gel-tubes and left undisturbed at room temperature for $30 \mathrm{~min}$ to allow clotting. Hereafter, samples were centrifuged at $2330 \mathrm{~g}$ at $4^{\circ} \mathrm{C}$ for $10 \mathrm{~min}$ to remove the clot. The resulting supernatant was immediately transferred into Eppendorf tubes and kept at $-80^{\circ} \mathrm{C}$ until analysis.

\section{Cell culture}

The wild type human colon cancer cell lines Caco-2, DLD-1, SW480, LoVo, LS174T and a CDX2 inducible LS174T cell line were used in this study. The CDX2 inducible LS174T cell line is genetically modified and are CDX2 knockout but contain inducible elements that enable activation of CDX2 expression by addition of doxycycline to the growth media [31]. LS174T cell lines were obtained from Assoc. Prof. Eric Paul Bennett. All cell lines were cultured in Dulbecco's Modified Eagle's Medium (DMEM) with Ultraglutamine with $4.5 \mathrm{~g} / \mathrm{L}$ Glucose (Lonza, Basel, Switzerland) supplemented with 10\% Fetal Bovine Serum (HyClone by Fisher Scientific, Waltham, MA, USA) and Penicillin (100 units $/ \mathrm{mL})$ Streptomycin $(100 \mu \mathrm{g} / \mathrm{mL})$ (Gibco by Life Technologies, Carlsbad, CA, USA) The cell cultures were incubated at $37^{\circ} \mathrm{C}$ in $5 \%$ $\mathrm{CO} 2$ and passaged every 3-4 days. The LS174T cells with inducible CDX2 were cultured in media with or without $4 \mathrm{ng} / \mathrm{ml}$ doxycycline to induce CDX2 expression.

\section{Adhesion measurement}

Real-Time Cell-Analysis (RTCA) iCELLigence (ACEA Biosciences, San Diego, CA, USA) was used to measure cell adhesion. The RTCA iCELLigence instrument uses electrical impedance as a readout to monitor changes in the cellular phenotype. The cell culture plates used in the instrument have electrodes placed at the bottom of each well, and cells attaching to the electrodes will lead to an increase in electrical impedance. The relative change in the electrical impedance is recorded as a dimensionless value termed Cell Index. The RTCA iCELLigence was set up using E-Plate L8 PET (ACEA Biosciences, San Diego, CA, USA) and cells in DMEM containing either $7 \%$ pre- or postoperative serum were added to each well in quadruplicates. For the LS174T cell line, $2 * 10^{4}$ cells were seeded in each well. For the Caco-2 cell line, $5^{*} 10^{3}$ cells were seeded in each well, while for the DLD-1, SW480, and LoVo, $1 * 10^{4}$ cells were seeded in each well. For LS174T cell with inducible
CDX2, 2*10 $0^{4}$ cells with or without $4 \mathrm{ng} / \mathrm{ml}$ doxycycline induced CDX2 expression were seeded in replicates in the E-plate L8 PET. The impedance was measured every $5 \mathrm{~min}$ and the difference in Cell Index at $60 \mathrm{~min}$ between cells seeded in preoperative and postoperative serum was calculated.

\section{Western blot}

Cells for protein extraction were seeded in 6-well plates at $5^{*} 10^{5}$ cells/well. After $24 \mathrm{~h}$ media was changed and LS174T cells with inducible CDX2 were added media with or without doxycycline. Cells were lysed after $72 \mathrm{~h}$ of doxycycline treatment by rising with cold PBS and incubated $5 \mathrm{~min}$ with $150 \mu \mathrm{l} /$ well $1 \mathrm{x}$ RIPA lysis buffer $(1 \mathrm{x}$ PBS, $300 \mathrm{mM} \mathrm{NaCl}, 1 \%$ Tergitol NP-40, 0.1\% SDS, 0.5\% 7-Deoxycholic acid sodium salt, $0.5 \mu \mathrm{M}$ EDTA pH 8.0) with freshly added $1 \mathrm{mM}$ DTT and $2 \mu \mathrm{l} / \mathrm{ml}$ protease inhibitor mix p8340 (Sigma-Aldrich, St. Louis, MO, USA). Lysate was centrifuged for $15 \mathrm{~min}$ at $12.000 \mathrm{~g}$ and $4{ }^{\circ} \mathrm{C}$. Supernatant was stored at $-20^{\circ} \mathrm{C}$. Protein concentration was determined by Bradford analysis (Bio-Rad, Hercules, CA, USA).

For the analysis, $10 \mu \mathrm{g}$ protein was mixed 1:4 (v/v) with Bolt loading buffer and 1:10 (v/v) with Bolt sample reducing agent (Thermo Fisher Scientific, Waltham, MA, USA). Samples were incubated at $95^{\circ} \mathrm{C}$ for $5 \mathrm{~min}$ and loaded on a Bolt $4-12 \%$ Bis-Tris Plus gel (Thermo Fisher Scientific, Waltham, MA, USA) PageRuler prestained protein ladder was used as marker (Thermo Fisher Scientific, Waltham, MA, USA). SDS-PAGE was performed in $1 \mathrm{X}$ Bolt MOPS running buffer (Thermo Fisher Scientific, Waltham, MA, USA) for $30 \mathrm{~min}$ at 25 $\mathrm{V}$, then $60 \mathrm{~min}$ at $120 \mathrm{~V}$. The gel was transferred by wetelectrotransfer to PVDF membrane for $60 \mathrm{~min}$ at $25 \mathrm{~V}$ in 1X NuPage transfer buffer (Thermo Fisher Scientific, Waltham, MA, USA). The membrane was blocked with dry skim milk diluted to $5 \%$ in Wash buffer (1X TBS with $0.1 \%$ Tween-20) for $1 \mathrm{~h}$ at room temperature. The membrane was washed with Wash buffer 5 times for 3 min and incubated overnight at $4{ }^{\circ} \mathrm{C}$ with primary antibody diluted in $2.5 \%$ skim milk in Wash buffer. The membrane was then washed 5 times for $3 \mathrm{~min}$ and incubated with diluted secondary antibody for $1 \mathrm{~h}$ at room temperature. Before visualization, the membrane was washed 5 times for $3 \mathrm{~min}$ and then visualized by incubating with the ECL solution SuperSignal West Dura Extended Duration Substrate for 5 min (Thermo Fisher Scientific, Waltham, MA, USA). Antibodies used: CDX2 1:1000 (BioGenex, Freemont, CA, USA, MU392A-UC); Vinculin 1:5000 (Abcam, Cambridge, UK, ab129002); Goat anti-rabbit HRP 1:10,000 (Thermo Fisher Scientific, Waltham, MA, USA, 32260); Goat anti-mouse HRP 1:10,000 (Thermo Fisher Scientific, Waltham, MA, USA, 32230). 


\section{Statistical analysis}

The paired Wilcoxon signed-rank test was used to determine statistical differences in the adhesion of cells with pre- and postoperative serum and the level of statistical significance was set at $p$-values $<0.01$. The RTCA iCELLigence data analysis software 1.0 and Graphpad Prism 8 software were used for statistical analysis.

\section{Results}

In total, 38 patients were enrolled in the study. Seven patients were excluded due to post-operative complications and one patient was excluded due to benign disease. A total of 30 patients, 19 male and 11 female, went through laparoscopic colon cancer surgery within an ERAS setting and were included in the study (see Table 1 for patient demographics). According to UICC staging [32], patients were diagnosed with stage I-III cancer. The patients had an ASA score [33] ranging from I to III and had between 0 and 2 in WHO Performance Status [34]. None of the patients had visible metastasis preoperatively. Serum from blood samples drawn on the day prior to surgery and the day after surgery was used for the analysis of adhesion.

Culturing five different colon cancer cell lines, LS174T, Caco-2, DLD-1, SW480, and LoVo, in media supplemented with perioperative serum from a single patient, showed increased adhesion abilities in cells seeded in postoperative serum compared to preoperative serum for all cell lines (Fig. 1a). The difference in Cell Index in percentage at $60 \mathrm{~min}$ varied from $3.5 \%$ in the LS174T cell line to $8.0 \%$ in the LoVo cell line (Fig. 1b). While all the cell lines showed varied extent of increase in adhesion in postoperative serum, we chose the LS174T cell line for testing our entire patient cohort consisting of 30 patients. This cell line was chosen as a genetically modified clone has been produced, which contains inducible elements that control the expression of CDX2 [31]. As a result, the cells do not express CDX2 without being induced. To our knowledge, this is the only colon cancer cell line still viable with complete depletion of CDX2 expression. In other CDX2 positive colon cancer cell lines, CDX2 acts as a linage survival gene that cannot be inactivated [35].

When investigating our cohort of 30 patients a significant difference in cell adhesion, with increased adhesion in wild type LS174T cells seeded in postoperative serum compared to preoperative serum was observed. A difference between the pre- and postoperative samples could be observed $20 \mathrm{~min}$ after seeding, and at $60 \mathrm{~min}$ the cells had adhered to the surface and no further increase in adhesion could be observed. The Cell Indexes at $60 \mathrm{~min}$ were for 26 out of 30 patients higher in the postoperative sample compared to the preoperative sample $(p<$ 0.0001) (Fig. 2a). Cell Indexes were slightly lower for
Table 1 Demographics for patients undergoing laparoscopic colonic resection for colon cancer

\begin{tabular}{|c|c|c|}
\hline \multicolumn{2}{|l|}{ Age, mean (SD) } & \multirow{2}{*}{$\frac{67,6(8,8)}{19(63,3)}$} \\
\hline Gender n (\%) & Male & \\
\hline & Female & $11(36,7)$ \\
\hline \multirow[t]{3}{*}{ ASA-score n (\%) } & 1 & $3(10,0)$ \\
\hline & 2 & $24(80,0)$ \\
\hline & 3 & $3(10,0)$ \\
\hline \multirow[t]{4}{*}{ BMI n (\%) } & $<18,5$ & $1(3,3)$ \\
\hline & $18.5-24.9$ & $12(40,0)$ \\
\hline & $25-29.9$ & $8(26,7)$ \\
\hline & $>30$ & $9(30,0)$ \\
\hline \multirow[t]{3}{*}{ Smoking n (\%) } & Current smoker & $5(16,7)$ \\
\hline & Former smoker & $13(43,3)$ \\
\hline & Never smoker & $12(40,0)$ \\
\hline \multirow[t]{2}{*}{ Alcohol (drinks/week) n (\%) } & $0-14 / 21$ & $25(83,3)$ \\
\hline & $>14 / 21$ & $5(16,7)$ \\
\hline \multirow[t]{4}{*}{ Charlson Comorbidity Index n (\%) } & 0 & $18(60,0)$ \\
\hline & 1 & $6(20,0)$ \\
\hline & 2 & $3(10,0)$ \\
\hline & Missing & $3(10,0)$ \\
\hline \multirow[t]{3}{*}{ WHO Performance status n (\%) } & 0 & $25(83,3)$ \\
\hline & 1 & $3(10,0)$ \\
\hline & 2 & $2(6,7)$ \\
\hline \multirow[t]{3}{*}{ UICC n (\%) } & 1 & $10(33,3)$ \\
\hline & 2 & $12(40,0)$ \\
\hline & 3 & $8(26,7)$ \\
\hline \multirow[t]{2}{*}{ Anesthesia n (\%) } & Intravenous & $20(66,7)$ \\
\hline & Inhalation & $10(33,3)$ \\
\hline \multirow[t]{5}{*}{ Laparoscopic procedure n (\%) } & Right hemicolectomy & $9(30,0)$ \\
\hline & Transverse colectomy & $1(3,3)$ \\
\hline & Left hemicolectomy & $1(3,3)$ \\
\hline & Sigmoidectomy & $18(60,0)$ \\
\hline & Complete colectomy & $1(3,3)$ \\
\hline
\end{tabular}

ASA American Society of Anesthesiologist Score, BMI Body Mass Index, UICC Union for International Cancer Control

three patients in the postoperative serum (Fig. 2b). The sera from one patient gave the same Cell Index before and after surgery.

To investigate the role of CDX2 in cell adhesion, the colon cancer cell line LS174T with inducible CDX2 was used. This cell line has previously been used to study the effect of CDX2 on intestinal transcriptional regulation [36-38]. Western blotting analysis of the LS174T wild type and LS174T with inducible CDX2 cells was performed to detect CDX2 levels. Results show no CDX2 expression in the LS174T with inducible CDX2 when not treated with doxycycline (Fig. 3a). When treated 

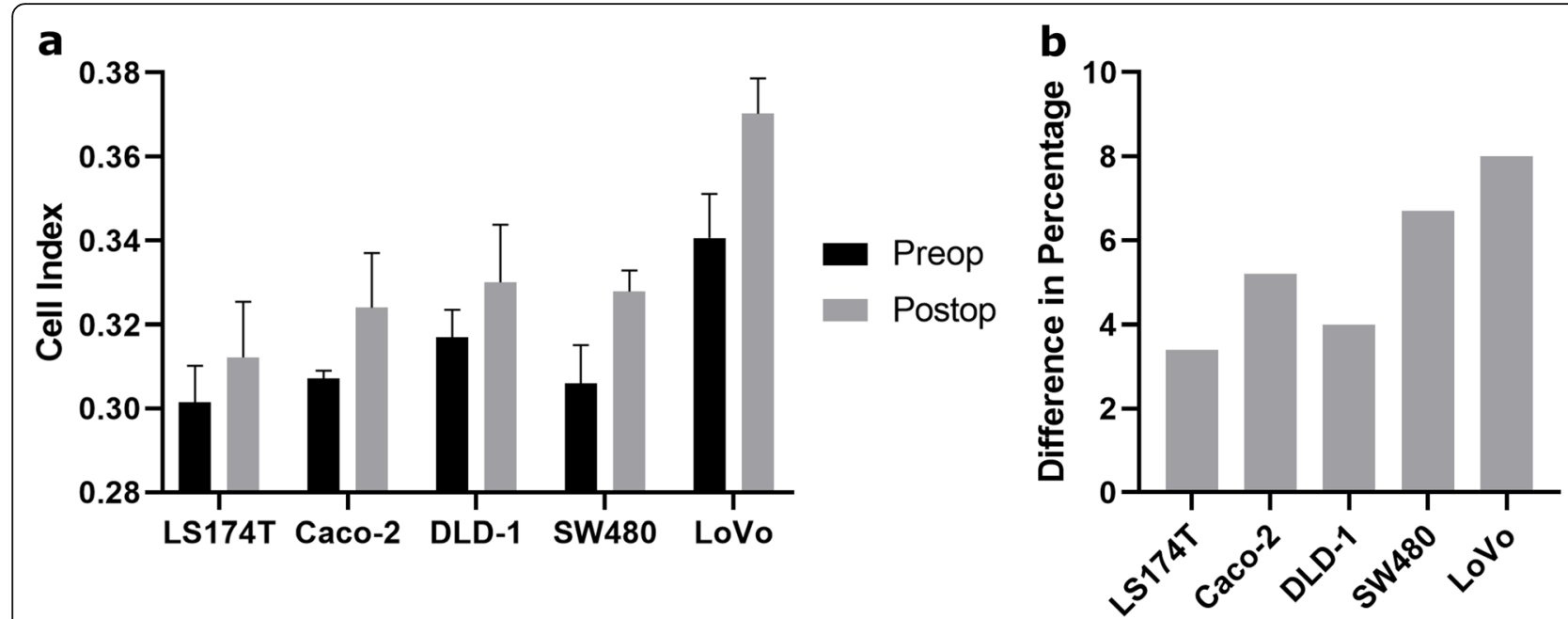

Fig. 1 Adhesion measurements of five different colon cancer cell lines in pre- or postoperative patient serum a. Cell adhesion of LS174T, Caco-2, DLD-1, SW480, and LoVo cells seeded in media with pre- or postoperative serum from one patient was measured. Mean Cell Index at 60 min is shown, $n=4$. $\mathbf{b}$. The difference in percentage between adhesion ability of cells seeded in postoperative serum compared to preoperative serum at 60 min was calculated for each cell line. The positive bars (grey) indicate higher adhesion in cells in postoperative serum compared to cells in preoperative serum

with doxycycline, expression of CDX2 was reestablished. Vinculin was used as a control to measure total protein loaded. When seeding CDX2 negative LS174T cells in pre- and postoperative patient serum no difference in adhesion between the two groups was seen $(p=0.21)$ (Fig. $3 \mathrm{~b})$. Out of the 30 patient samples, only 11 had increased adhesion for cells seeded in postoperative serum compared to preoperative serum
(Fig. 3c). However, when the cells had induced CDX2 at wild type levels, the results resembled those seen in the wild type LS174T cells, with significantly increased adhesion in postoperative serum compared to preoperative serum $(p<0.0001)$ (Fig. $3 \mathrm{~d})$. Twenty-six patients out of 30 showed increased adhesion for cells seeded in postoperative serum compared to preoperative serum (Fig. 3e).
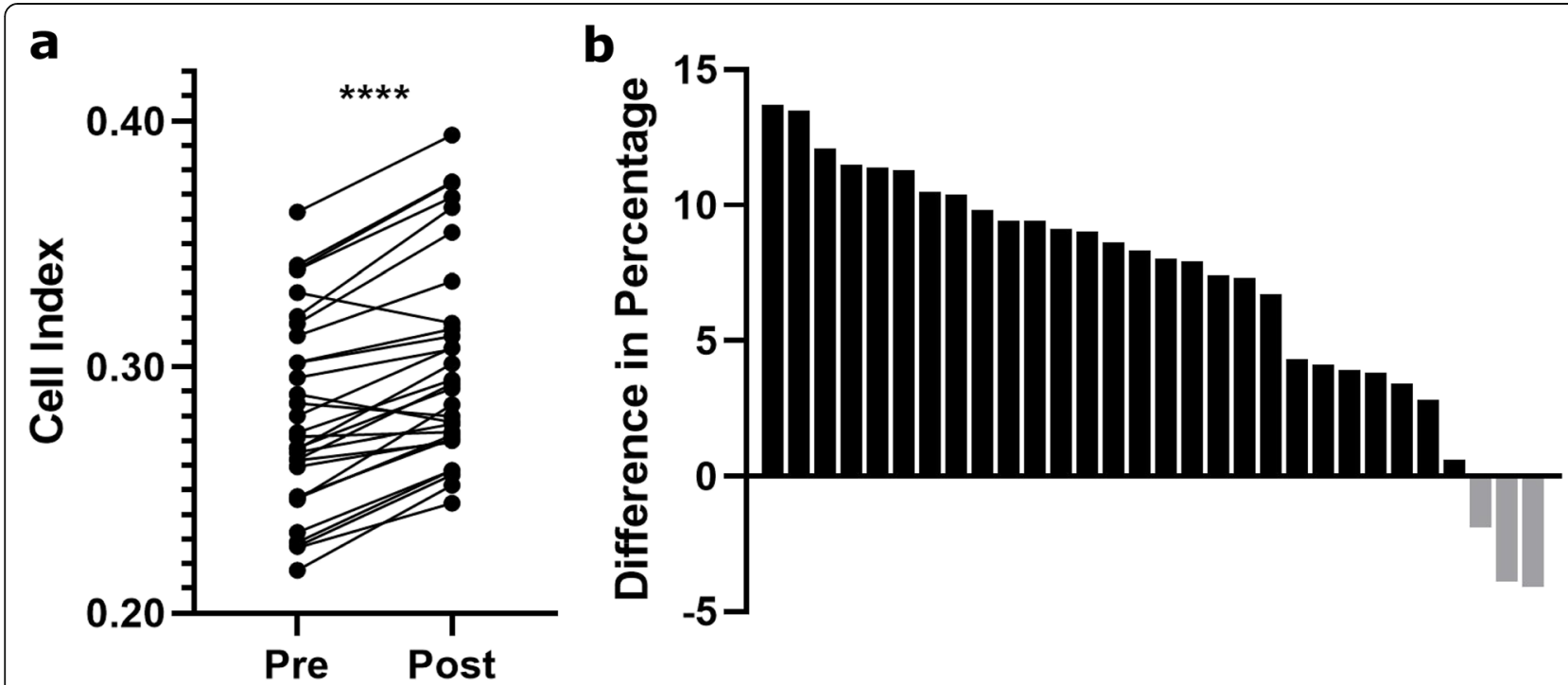

Fig. 2 Adhesion measurements in wild type LS174T cells a. The Cell Index for wild type LS174T cells seeded in pre- and postoperative serum was measured for each patient. Mean results at $60 \mathrm{~min}$ for pre- and postoperative cell adhesion for each patient is shown. ${ }^{* * *} p<0.0001$. b. The difference in percentage in adhesion at $60 \mathrm{~min}$ was calculated for each patient. The positive bars (black) indicate patients with higher adhesion in cells in postoperative compared to preoperative serum, while the negative bars (grey) indicate patients with higher adhesion in cells in preoperative compared to postoperative serum 


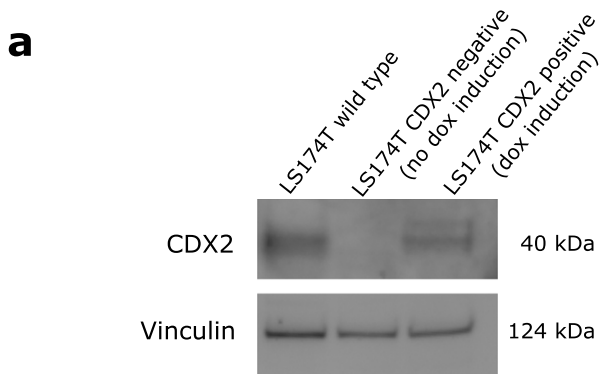

LS174T CDX2 negative cells
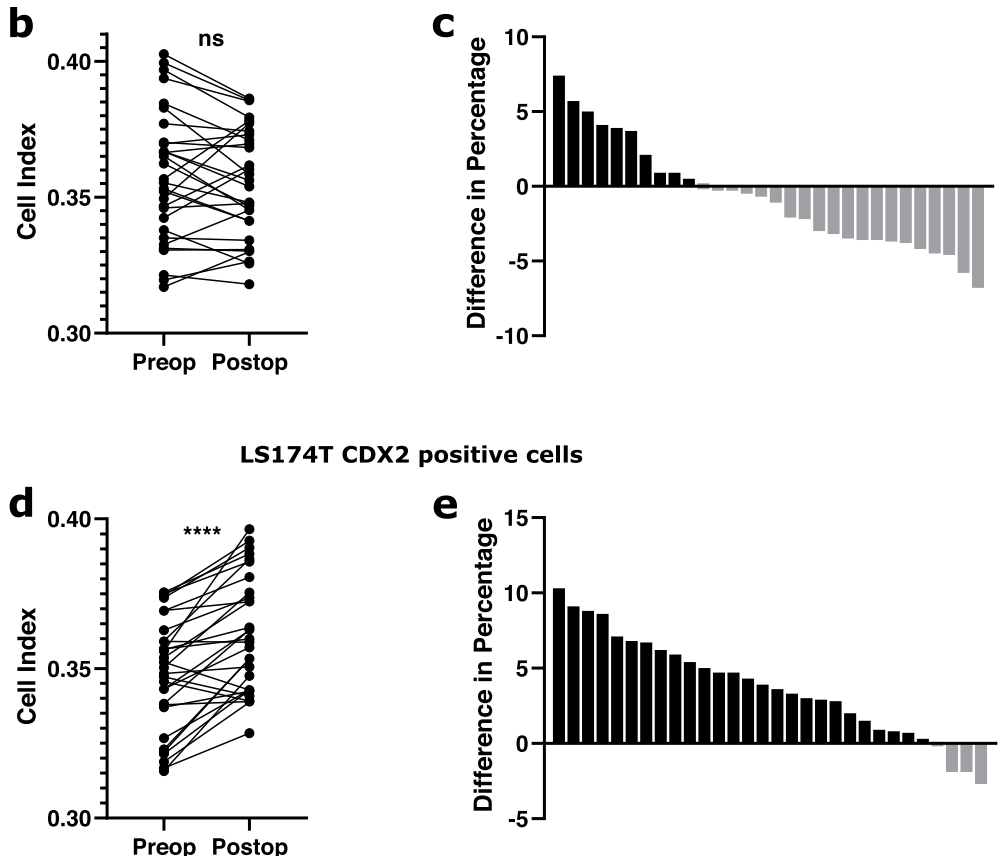

Fig. 3 Adhesion measurements in CDX2 inducible LS174T cells a. CDX2 protein expression was compared using western blotting. Cell lysate from LS174T wild type cells and LS174T cells with inducible CDX2 with or without doxycycline treatment was used in the analysis. Vinculin was used as a control. Bands are from the same gel $\mathbf{b}$. The Cell Index for CDX2 negative LS174T cells seeded in pre- and postoperative serum was measured. Mean results at 60 min for pre- and postoperative cell adhesion for each patient is shown. n.s. = not significant. c. The difference in percentage in adhesion at 60 min was calculated for each patient. The positive bars (black) indicate patients with higher adhesion in postoperative compared to preoperative serum, while the negative bars (grey) indicate patients with higher adhesion in preoperative compared to postoperative serum. $\mathbf{d}$. The Cell Index for CDX2 positive LS174T cells seeded in pre- and postoperative serum was measured. Mean results at 60 min for pre- and postoperative cell adhesion for each patient is shown. ${ }^{* * *} p<0.0001$. e. The difference in percentage in adhesion at 60 min was calculated for each patient. The positive bars (black) indicate patients with higher adhesion in postoperative compared to preoperative serum, while the negative bars (grey) indicate patients with higher adhesion in preoperative compared to postoperative serum

When comparing cell adhesion in cells treated with preoperative serum samples, there was a significant increase in adhesion in the CDX2 negative cells compared to the CDX2 positive cells $(p<0.001)$ (Fig. 4a). For the cells treated with postoperative serum, the CDX2 positive cells had significantly increased adhesion compared to the CDX2 negative cells $(p<0.001)$ (Fig. $4 \mathrm{~b})$.

\section{Discussion}

In this study, we established an in vitro method for measuring the effect of perioperative factors on the adhesion ability of the LS174T colon cancer cell line using serum from patients undergoing colon cancer surgery. Commonly used methods for cell adhesion assays typically include staining attached cells and using fluorescence for endpoint measurements [39-41], but by using the method developed in this paper, it is possible to monitor real-time cell adhesion for the entire adhesion period. While this method does not allow us to distinguish between initial sedimentation, cell attachment, cell spreading and stable cell adhesion, the mentioned are all part of the passive cell adhesion process [42]. 


\section{Preop}

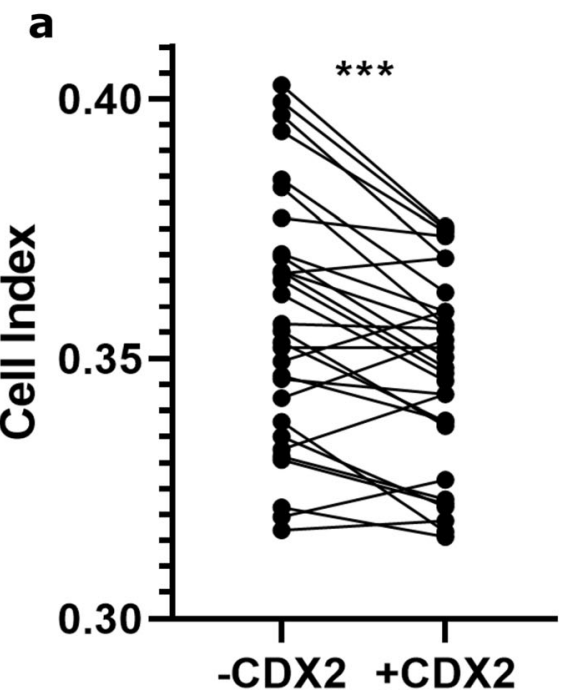

\section{Postop}

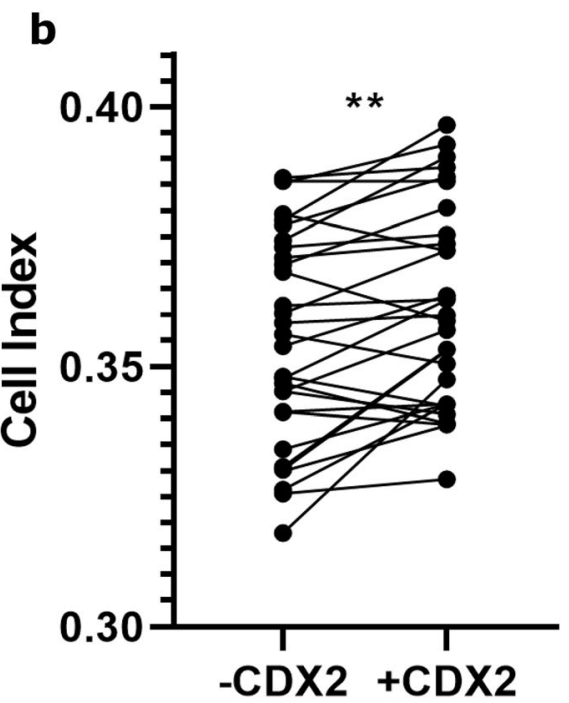

Fig. 4 Adhesion measurement of CDX2 inducible LS174T cells in pre- and postoperative serum a. The Cell Index for CDX2 negative and CDX2 positive inducible LS174T cells seeded in preoperative serum was measured. Mean results at 60 min for each patient is shown. ${ }^{* *} p<0.001$. $\mathbf{b}$. The Cell Index for CDX2 negative and CDX2 positive inducible LS174T cells seeded in postoperative serum was measured. Mean results at 60 min for each patient is shown. ${ }^{* *} p<0.01$

Investigating the adhesion abilities of the cells on a surface that more resembles the in vivo biological surface cancer cells interact with during metastasis may provide further insight to the adhesion process examined in this study.

Our study identified significantly increased cell adhesion abilities in five different colon cancer cell lines in postoperative serum, and further investigation using genetically modified LS174T cells showed this increase in adhesion to be eliminated by lack of CDX2 expression. This indicates that the absence of CDX2 expression results in reduced cancer cell adherence, and that fluctuation of CDX2 levels in cancer cells could be important in the metastatic process of colon cancer cells.

CDX2 has been shown to regulate the expression of a number of claudins [43,44], a critical component of the tight junctions in epithelial cells. Aberrant expression of claudins has been seen in a variety of cancers, and it has been hypothesized that reduced claudin expression promotes tumorigenesis and metastasis by increasing the motility and invasion of cancer cells [9]. Studies have shown that reduced expression of claudin-1 is a predictor of poor prognosis and reduced disease-free survival [45-47], and that knockdown of claudin-1 expression in colon cancer cell lines significantly increase cell invasiveness [45]. Reduced expression of claudin-7 has been shown to be an early event in colorectal carcinogenesis [48], and downregulation of claudin-7 promotes EMT $[49,50]$. Expression of claudin-23 has been shown to be downregulated in tumour tissue and downregulation is associated with shorter overall survival in patients with colorectal tumours [51]. Furthermore, CDX2 has been shown to mediate E-selectin ligand expression in colon cancer cells [52], a crucial component in the attachment of cancer cells to distant tissues during metastasis [10].

Exogenous CDX2 expression has been shown to be associated with reduced cell invasion in Lovo cells transfected with CDX2 overexpression plasmid [53], indicating that CDX2 may play a role in other metastatic processes besides adhesion. Other components have also been shown to influence the metastatic processes of adhesion, invasion and migration, such as the G-protein coupled receptor 55 [54], and the C-type lectin DC-SIGNR [55].

The observed difference in adhesion property between cells in pre- versus postoperative serum is most likely due to factors released into the bloodstream in patients during or after surgery. Previous studies have shown that pro-inflammatory cytokines mediate the adhesion of cancer cells to mesothelial and endothelial monolayers in vitro $[13,14]$. Changes in expression of cell adhesion molecules in colon cancer cells have been associated with progression of cancer. This alteration in adhesion molecules could potentially facilitate the adhesion enabling intravasation as well as extravasation and may be part of organ selectivity in metastatic processes [15]. Furthermore, changes in expression of adhesion molecules could also affect postoperative cancer cell survival, as circulating tumour cells are vulnerable and depend on fast attachment in order to survive [2]. 
The underlying mechanisms of the interaction between the cellular adhesion molecules and factors in the patient serum has not yet been determined. However, when seeding the cells in patient serum, we can already measure altered adhesion abilities between cells in prevs postoperative serum $20 \mathrm{~min}$ after seeding. This rapid response indicates that factors in the patient serum directly affects the adhesion molecules already expressed on the surface of the cells or in the cytoplasm. Previously, RNA sequencing of the CDX2 inducible LS174T cell line used in our study showed altered RNA levels of several integrins, including integrin $\alpha 3, \alpha 6, \beta 4$, and $\beta 6$, in cells without CDX2 expression compared to wild-type LS174T cells [31]. Given the importance of the postoperative elevated adhesion and its possible correlation with recurrence, an identification of the precise mechanisms behind the interaction may provide valuable knowledge in reducing disease recurrence.

\section{Conclusions}

CDX2 expression is low in invasive colorectal cancer cells but is restored in metastases to a level corresponding to that of the primary tumour [26]. Our results show that CDX2 expression influences the adhesion ability of cultured colon cancer cells, and indicates that adjustments in CDX2 expression levels in cancer cells during EMT and MET is vital in the metastatic process of colon cancer. In conclusion, we demonstrate an in vitro method for measuring the effect of perioperative factors on the adhesion ability of the LS174T colon cancer cell line using serum form patients undergoing colon cancer surgery, and we demonstrate a differential effect on adhesion depending on CDX2 expression. If results from the method developed in this study can be shown to correlate with clinical oncological outcomes, the method may be applied in studies examining perioperative interventions in respect to their effect on short and longterm oncological outcomes after surgery.

\section{Abbreviations}

ASA: American society of Anaesthesiologists; BMl: Body Mass Index; CDX2: Caudal Type Homeobox 2; DMEM: Dulbecco's Modified Eagle's Medium; EMT: Epithelial-to-Mesenchyme Transition; ERAS: Enhanced Recovery After Surgery; MET: Mesenchyme-to-Epithelial Transition; RCTA: Real-Time Cell-Analysis; SSR: Surgical Stress Response; UICC: Union for International Cancer Control

\section{Acknowledgements}

We would like to thank Assoc. Professor Eric Paul Bennet for providing the cell lines used in this study.

\section{Authors' contributions}

JD, SBJ, SKW, SL, KD, TK, IG, and JTT conceived and designed the experiments. SKW, TK, and IG enrolled patients into the study and took blood samples. JD and SBJ performed the experiments. JD, SBJ, and JTT analyzed the data and performed statistical analysis. JD, SBJ, and SKW drafted the original manuscript. JD, SBJ, SKW, SL, KD, TK, IG, and JTT reviewed and edited the final manuscript. The author(s) read and approved the final manuscript.

\section{Funding}

The work has been supported by The Danish Council for Independent Research for Health and Disease, grant no. 4004-00140B. The funder had no role in the design of the study, in collection, analysis and interpretation of the data, or in writing the manuscript.

\section{Availability of data and materials}

The datasets used and/or analysed during the current study are available from the corresponding author on reasonable request.

\section{Ethics approval and consent to participate}

All procedures performed in studies involving human participants were in accordance with the ethical standards of The Danish National Committee on Health Research Ethics, Region Zealand (file no: 2008-58-0020), and approved by the Danish Data Protection agency (protocol: SJ567). Informed oral and written consent was obtained from all individual participants included in the study.

Consent for publication

Not applicable.

\section{Competing interests}

The authors declare that they have no competing interests.

\section{Author details}

${ }^{1}$ Department of Science and Environment, Enhanced Perioperative Oncology (EPeOnc) Consortium, Roskilde University, Universitetsvej 1, 4000 Roskilde, Denmark. ${ }^{2}$ Center for Surgical Science, Enhanced Perioperative Oncology (EPeOnc) Consortium, Department of Surgery, Zealand University Hospital, Lykkebækvej 1, 4600 Køge, Denmark. ${ }^{3}$ Department of Clinical Immunology, Naestved Hospital, Ringstedgade 77B, 4700 Naestved, Denmark.

Received: 17 January 2020 Accepted: 10 May 2020

Published online: 14 May 2020

\section{References}

1. Bray F, Ferlay J, Soerjomataram I, Siegel RL, Torre LA, Jemal A. Global cancer statistics 2018: GLOBOCAN estimates of incidence and mortality worldwide for 36 cancers in 185 countries. CA Cancer J Clin. 2018;68(6):394-424 Available from: http://www.ncbi.nlm.nih.gov/pubmed/30207593.

2. van der Bij GJ, Oosterling SJ, Beelen RHJ, Meijer S, Coffey JC, van Egmond M. The perioperative period is an underutilized window of therapeutic opportunity in patients with colorectal cancer. Ann Surg. 2009;249(5):727-34.

3. Yamaguchi K, Takagi Y, Aoki S, Futamura M, Saji S. Significant detection of circulating cancer cells in the blood by reverse transcriptase-polymerase chain reaction during colorectal cancer resection. Ann Surg. 2000;232(1):58-65.

4. Neeman E, Ben-Eliyahu S. Surgery and stress promote cancer metastasis: new outlooks on perioperative mediating mechanisms and immune involvement. Brain Behav Immun. 2013;30:S32.

5. Läubli H, Borsig L. Altered cell adhesion and glycosylation promote Cancer immune suppression and metastasis. Front Immunol. 2019;10(September):1-9.

6. Horowitz M, Neeman E, Sharon E, Ben-eliyahu S. Exploiting the critical perioperative period to improve long-term cancer outcomes. Nat Publ Gr. 2015;12(April):213-26.

7. Shibata H, Takano H, Ito M, Shioya H, Hirota M, Matsumoto H, et al. Catenin is essential in intestinal adenoma formation. Proc Natl Acad Sci. 2007; 104(46):18199-204.

8. Aamodt R, Bondi J, Andersen SN, Bakka A, Bukholm G, Bukholm IRK. The prognostic impact of protein expression of E-cadherin-catenin complexes differs between rectal and Colon carcinoma. Gastroenterol Res Pract. 2010; 2010:1-7.

9. Tabariès S, Siegel PM. The role of claudins in cancer metastasis. Oncogene. 2017;36(9):1176-90.

10. Tremblay PL, Huot J, Auger FA. Mechanisms by which E-selectin regulates diapedesis of colon cancer cells under flow conditions. Cancer Res. 2008; 68(13):5167-76.

11. Robertson $\mathrm{JH}$, Yang SY, Winslet MC, Seifalian AM. Functional blocking of specific integrins inhibit colonic cancer migration. Clin Exp Metastasis. 2009; 26(7):769-80.

12. Gallicchio M, Rosa AC, Dianzani $C$, Brucato $L$, Benetti $E$, Collino M, et al. Celecoxib decreases expression of the adhesion molecules ICAM-1 and 
VCAM-1 in a colon cancer cell line (HT29). Br J Pharmacol. 2008;153(5):8708.

13. Ten Kate M, Hofland LJ, van Grevenstein WMU, van Koetsveld PV, Jeekel J, van Eijck CHJ. Influence of proinflammatory cytokines on the adhesion of human colon carcinoma cells to lung microvascular endothelium. Int J Cancer. 2004 Dec;112(6):943-50.

14. Ziprin P, Ridgway PF, Pfister Uller KLM, Peck DH, Darzi AW. ICAM-1 mediated tumor-Mesothelial cell adhesion is modulated by IL- 6 and TNF-a: a potential mechanism by which surgical trauma increases peritoneal metastases. Cell Commun Adhes. 2003;10:141-54.

15. Paschos KA, Canovas D, Bird NC. The role of cell adhesion molecules in the progression of colorectal cancer and the development of liver metastasis; 2009.

16. Olsen AK, Coskun M, Bzorek M, Kristensen MH, Danielsen ET, Jørgensen S, et al. Regulation of APC and AXIN2 expression by intestinal tumor suppressor CDX2 in colon cancer cells. Carcinogenesis. 2013 Jun;34(6):13619.

17. Hryniuk A, Grainger S, Savory JGA, Lohnes D. Cdx1 and Cdx2 function as tumor suppressors. J Biol Chem. 2014;289(48):33343-54.

18. Bonhomme C, Duluc I, Martin E, Chawengsaksophak K, Chenard M, Kedinger M, et al. The CDX2 homeobox gene has a tumour supressor function in the distal colon in addition to a homeotic role during gut development. Gut. 2003;52(10):1465-71.

19. Platet N, Hinkel I, Richert L, Murdamoothoo D, Moufok-Sadoun A, Vanier M, et al. The tumor suppressor CDX2 opposes pro-metastatic biomechanical modifications of colon cancer cells through organization of the actin cytoskeleton. Cancer Lett. 2017;386:57-64. Available from:. https://doi.org/10. 1016/j.canlet.2016.10.040.

20. Balbinot C, Armant O, Elarouci N, Marisa L, Martin E, de Clara E, et al. The $\mathrm{Cd} \times 2$ homeobox gene suppresses intestinal tumorigenesis through noncell-autonomous mechanisms. J Exp Med. 2018;215(3):911-26.

21. Olsen J, Espersen MLM, Jess P, Kirkeby L, Troelsen JT. The clinical perspectives of CDX2 expression in colorectal cancer: a qualitative systematic review. Surg Oncol. 2014;23(3):167-76.

22. Bruun J, Sveen A, Barros R, Eide PW, Eilertsen I, Kolberg M, et al. Prognostic, predictive, and pharmacogenomic assessments of CDX2 refine stratification of colorectal cancer. Mol Oncol. 2018;12(9):1639-55.

23. Zhang BY, Jones JC, Briggler AM, Hubbard JM, Kipp BR, Sargent DJ, et al. Lack of caudal-type Homeobox transcription factor 2 expression as a prognostic biomarker in metastatic colorectal Cancer. Clin Colorectal Cancer. 2017;16(2):124-8. Available from:. https://doi.org/10.1016/j.clcc.2016. 09.003.

24. Guo RJ, Funakoshi S, Lee HH, Kong J, Lynch JP. The intestine-specific transcription factor $\mathrm{Cd} \times 2$ inhibits b-catenin/TCF transcriptional activity by disrupting the b-catenin-TCF protein complex. Carcinogenesis. 2010;31(2): 159-66.

25. Dalerba P, Sahoo D, Paik S, Guo X, Yothers G, Song N, et al. CDX2 as a prognostic biomarker in stage II and stage III Colon Cancer. N Engl J Med. 2016;374(3):211-22. Available from:. https://doi.org/10.1056/NEJMoa1506597.

26. Brabletz T, Spaderna S, Kolb J, Hlubek F, Faller G, Bruns CJ, et al. Downregulation of the Homeodomain factor $\mathrm{Cd} \times 2$ in colorectal Cancer by collagen type I. Cancer Res. 2004;64(19):6973-7.

27. Zhang JF, Qu LS, Qian XF, Xia BL, Mao ZB, Chen WC. Nuclear transcription factor CDX2 inhibits gastric cancer-cell growth and reverses epithelial-to-mesenchymal transition in vitro and in vivo. Mol Med Rep. 2015;12(4):5231-8.

28. Gross I, Duluc I, Benameur T, Calon A, Martin E, Brabletz T, et al. The intestine-specific homeobox gene $\mathrm{Cd} \times 2$ decreases mobility and antagonizes dissemination of colon cancer cells. Oncogene. 2008;27(1):107-15.

29. Subtil C, Guérin E, Schneider A, Chenard MP, Martin E, Domon-Dell C, et al. Frequent rearrangements and amplification of the CDX2 homeobox gene in human sporadic colorectal cancers with chromosomal instability. Cancer Lett. 2007;247(2):197-203.

30. Eriksen JR, Munk-Madsen P, Kehlet H, Gögenur I. Orthostatic intolerance in enhanced recovery laparoscopic colorectal resection. Acta Anaesthesiol Scand. 2019;63(2):171-7.

31. Pinto R, Hansen L, Hintze J, Almeida R, Larsen S, Coskun M, et al. Precise integration of inducible transcriptional elements (PrllTE) enables absolute control of gene expression. Nucleic Acids Res. 2017;45:13.

32. Brierley JD, Gospodarowicz MK, Wittekind C. TNM Classification of Malignant Tumours. 8th ed. Hoboken: Wiley-Blackwell; 2016. p. 73-6.
33. Abouleish AE, Lieb ML, Cohen NH. ASA provides examples to each physical Status class. ASA Monit. 2015;79(6):28-49.

34. West HJ, Jin JO. Performance Status in Patients With Cancer. JAMA Oncol. 2015;1(7):998. Available from. https://doi.org/10.1001/jamaoncol.2015.3113.

35. Salari K, Spulak ME, Cuff J, Forster AD, Giacomini CP, Huang S. CDX2 is an amplified lineage-survival oncogene in colorectal cancer. PNAS Plus. 2012; 109(46):3196-205

36. Larsen S, Davidsen J, Dahlgaard K, Pedersen OB, Troelsen JT. HNF4a and CDX2 regulate intestinal YAP1 promoter activity. Int J Mol Sci. 2019 Jun;18: 20(12).

37. Danielsen ET, Olsen AK, Coskun M, Nonboe AW, Larsen S, Dahlgaard K, et al. Intestinal regulation of suppression of tumorigenicity 14 (ST14) and serine peptidase inhibitor, Kunitz type -1 (SPINT1) by transcription factor CDX2. Sci Rep. 2018;8(1):1-14.

38. Davidsen J, Larsen S, Coskun M, Gögenur I, Dahlgaard K, Bennett EP, et al. The VTI1A-TCF4 colon cancer fusion protein is a dominant negative regulator of Wnt signaling and is transcriptionally regulated by intestinal homeodomain factor CDX2. PLoS One. 2018;13:7.

39. Sato Y, Kubo T, Morimoto K, Yanagihara K, Seyama T. High mannosebinding Pseudomonas fluorescens lectin (PFL) downregulates cell surface integrin/EGFR and induces autophagy in gastric cancer cells. BMC Cancer [Internet]. 2016;16(1):1-13. Available from: http://www.embase.com/search/ results?subaction=viewrecord\&from $=$ export\&id=L608079372\%5Cnhttp://dx. doi.org/10.1186/s12885-016-2099-2\%5Cnhttp://findit.library.jhu.edu/ resolve?sid=EMBASE\&issn=14712407\&id=doi:10.1186/s12885-016-20992\&atitle=High+mannose-bindi.

40. Ponda MP, Breslow JL. Serum stimulation of CCR7 chemotaxis due to coagulation factor XIla-dependent production of high-molecular-weight kininogen domain 5. Proc Natl Acad Sci [Internet]. 2016;113(45):E7059-68. Available from:. https://doi.org/10.1073/pnas.1615671113.

41. Li J, Bowens N, Cheng L, Zhu X, Chen M, Hannenhalli S, et al. Myocardin-like protein 2 regulates TGF signaling in embryonic stem cells and the developing vasculature. Development. 2012;139(19):3531-42. Available from: https://doi.org/10.1242/dev.082222.

42. Khalili AA, Ahmad MR. A review of cell adhesion studies for biomedical and biological applications. Int J Mol Sci. 2015;16(8):18149-84.

43. Sakaguchi T, Gu X, Golden HM, Suh E, Rhoads DB, Reinecker HC. Cloning of the human claudin-2 5'-flanking region revealed a TATA-less promoter with conserved binding sites in mouse and human for caudal-related homeodomain proteins and hepatocyte nuclear factor-1a. J Biol Chem. 2002;277(24):21361-70.

44. Satake S, Semba S, Matsuda Y, Usami Y, Chiba H, Sawada N, et al. Cdx2 transcription factor regulates claudin-3 and claudin-4 expression during intestinal differentiation of gastric carcinoma. Pathol Int. 2008;58(3):156-63.

45. Nakagawa S, Miyoshi N, Ishii H, Mimori K, Tanaka F, Sekimoto M, et al. Expression of CLDN1 in colorectal cancer: a novel marker for prognosis. Int J Oncol. 2011;39(4):791-6.

46. Shibutani M, Noda E, Maeda K, Nagahara H, Ohtani H, Hirakawa K. Low expression of claudin-1 and presence of poorly-differentiated tumor clusters correlate with poor prognosis in colorectal cancer. Anticancer Res. 2013; 33(8):3301-6 Available from: http://www.ncbi.nlm.nih.gov/pubmed/23 898096.

47. Yoshida T, Kinugasa T, Akagi Y, Kawahara A, Romeo K, Shiratsuchi I, et al. Decreased expression of claudin-1 in rectal cancer: a factor for recurrence and poor prognosis. Anticancer Res. 2011;31(7):2517-25 Available from: http://www.ncbi.nlm.nih.gov/pubmed/21873169.

48. Bornholdt J, Friis S, Godiksen S, Poulsen SS, Santoni-Rugiu E, Bisgaard HC, et al. The level of claudin-7 is reduced as an early event in colorectal carcinogenesis. BMC Cancer. 2011;11(1):65 Available from: http://www. biomedcentral.com/1471-2407/11/65.

49. Wang K, Li T, Xu C, Ding Y, Li W, Ding L. Claudin-7 downregulation induces metastasis and invasion in colorectal cancer via the promotion of epithelialmesenchymal transition. Biochem Biophys Res Commun. 2019;508(3):797804. Available from. https://doi.org/10.1016/j.bbrc.2018.10.049.

50. Bhat AA, Pope JL, Smith JJ, Ahmad R, Chen X, Washington MK, et al. Claudin-7 expression induces mesenchymal to epithelial transformation (MET) to inhibit colon tumorigenesis. Oncogene. 2015;34(35):4570-80 Available from: http://www.nature.com/articles/onc2014385.

51. Pitule P, Vycital O, Bruha J, Novak P, Hosek P, Treska V, et al. Differential expression and prognostic role of selected genes in colorectal cancer patients. Anticancer Res. 2013;33(11):4855-66. 
52. Sakuma K, Aoki M, Kannagi R. Transcription factors c-Myc and CDX2 mediate E-selectin ligand expression in colon cancer cells undergoing EGF/ bFGF-induced epithelial-mesenchymal transition. Proc Natl Acad Sci. 2012; 109(20):7776-81.

53. Zheng JB, Sun XJ, Qi J, Li SS, Wang W, Ren HL, et al. Effects of homeodomain protein CDX2 expression on the proliferation and migration of Lovo colon cancer cells. Pathol Oncol Res. 2011;17(3):743-51.

54. Kargl J, Andersen L, Hasenöhrl C, Feuersinger D, Stančic A, Fauland A, et al. GPR55 promotes migration and adhesion of colon cancer cells indicating a role in metastasis. Br J Pharmacol. 2016;173(1):142-54.

55. Na H, Liu X, Li X, Zhang X, Wang Y, Wang Z, et al. Novel roles of DC-SIGNR in colon cancer cell adhesion, migration, invasion, and liver metastasis. J Hematol Oncol [Internet]. 2017;10(1):1-18. Available from:. https://doi.org/10. 1186/s13045-016-0383-x.

\section{Publisher's Note}

Springer Nature remains neutral with regard to jurisdictional claims in published maps and institutional affiliations.

- fast, convenient online submission

- thorough peer review by experienced researchers in your field

- rapid publication on acceptance

- support for research data, including large and complex data types

- gold Open Access which fosters wider collaboration and increased citations

- maximum visibility for your research: over $100 \mathrm{M}$ website views per year

At $\mathrm{BMC}$, research is always in progress. 